\title{
The late results of gastric surgery
}

\author{
C. N. Pulvertaft \\ County Hospital, York
}

THE PERFECT treatment for duodenal ulcer has yet to be developed.

The popular operation, at the moment, is vagotomy, total or selective, combined with pyloroplasty. It is known that, in the hands of the experts, like Burge of London, and Holt (Holt \& Lythgoe, 1965) of Manchester, the results are extremely satisfactory, but time alone will prove whether it will be as successful when applied generally throughout the country.

The nutritional complications of Polya resection are well documented, but there are, as yet, few long term studies in this country of vagotomy combined with antrectomy, gastro-enterostomy or pyloroplasty; and these operations have still to be fully evaluated. The late results of gastric surgery are, however, to a large extent, the outcome of the first post-operative months or years, and, at this time we can only attempt to predict the future on the basis of our present knowledge.

\section{Early results}

It is very difficult to make completely fair comparisons of operations but since 1959 we (Leeds and York)* have attempted to evaluate vagotomy in association with gastro-enterostomy or antrectomy, and Polya resections in a controlled clinical trial. It is unfortunate, in some respects, that we did not include pyloroplasty in that trial, but since the end of the trial this has been the operation of choice in both Leeds and York, and so, in due course, we will be able to make some comparisons, if not entirely accurate, between this and the other three operations. I am only going to refer briefly to this trial today, and the data I am showing is part of that presented by Professor Goligher to a Conference held in Glasgow in 1965 (Goligher, Pulvertaft \& Franz, 1966).

There were 507 male duodenal ulcers in this trial (Table 1).

*Surgeons contributing cases to the trial were Digby Chamberlain (deceased), H. L. Duthie, J. C. Goligher, A. J. C. Latchmore and F. G. Smiddy of the General Infirmary, Leeds; D. B. Feather of St James's Hospital, Leeds; and J. H. Conyers, R. A. Hall and J. K. Willson-Pepper of the York Hospitals.
TABLE 1

Disposal of 507 male duodenal ulcer patients in and out of trial

\begin{tabular}{lrrrr}
\hline & & \multicolumn{3}{c}{ Accepted into trial } \\
\cline { 3 - 5 } & Rejected & $\begin{array}{c}\text { Vagotomy } \\
\text { \& gastro- } \\
\text { enter- } \\
\text { ostomy }\end{array}$ & $\begin{array}{c}\text { \& } \begin{array}{c}\text { antrec- } \\
\text { tomy }\end{array} \\
\text { (tomy }\end{array}$ & $\begin{array}{c}\text { Gastrec- } \\
\text { tomy }\end{array}$ \\
\hline No. in each group & 132 & 126 & 132 & 117 \\
Operative deaths & 0 & 0 & 0 & 0 \\
Subsequent deaths & 4 & 4 & 9 & 3 \\
Untraced cases & 3 & 2 & 0 & 6 \\
Traced cases & 125 & 120 & 123 & 108 \\
\hline
\end{tabular}

From Goligher, Pulvertaft \& Franz (1966).

The overall clinical grading three years after operation is shown in Table 2. The method of grading is the usual York method, generally described as the Visick method. It is clear that, at least on this form of assessment, Polya resection compares favourably with either of the other two operations.

TABLE 2

Overall grading of functional results at 3 years

\begin{tabular}{|c|c|c|c|}
\hline Grade & $\begin{array}{c}\text { Vagotomy \& } \\
\text { gastro- } \\
\text { enterostomy } \\
\text { (\% of } 99 \text { cases) }\end{array}$ & $\begin{array}{l}\text { Vagotomy } \\
\text { \& antrectomy } \\
\text { (\% of } 94 \text { cases) }\end{array}$ & $\begin{array}{c}\text { Subtotal } \\
\text { gastrectomy } \\
\text { (\% of } 74 \text { cases) }\end{array}$ \\
\hline $\begin{array}{l}\text { I } \\
\text { II } \\
\text { III } \\
\text { IV }\end{array}$ & $\left.\begin{array}{l}52 \\
22 \\
19 \\
7\end{array}\right\} 74$ & $\left.\begin{array}{c}54 \\
24 \\
16 \\
6\end{array}\right\} 78$ & $\left.\begin{array}{l}56 \\
24 \\
12 \\
8\end{array}\right\} 80$ \\
\hline
\end{tabular}

From Goligher et al. (1966).

The frequency of different symptoms is shown in Table 3. They are of very similar order except for early dumping and diarrhoea, but if we consider these in more detail most of the early dumping (Table 4) is of mild degree and while the frequency of moderate or severe types is higher after resection, the numerical difference is quite small.

While the frequency of diarrhoea following 
vagotomy and drainage is greater than after subtotal gastrectomy the percentage of patients with severe diarrhoea is again small- $4 \%$ after vagotomy and gastro-enterostomy, $1 \%$ for vagotomy and antrectomy, and 0 for Polya (Table 5).

TABLE 3

Symptoms due to disturbance of alimentary function after operation

\begin{tabular}{lccc}
\hline Symptoms & $\begin{array}{c}\text { Vagotomy \& } \\
\text { gastro- } \\
\text { enterostomy } \\
\text { (\% of } \\
120 \text { cases) }\end{array}$ & $\begin{array}{c}\text { Vagotomy \& } \\
\text { antrectomy } \\
\text { (\% of } \\
123 \text { cases) }\end{array}$ & $\begin{array}{c}\text { Subtotal } \\
\text { gastrectomy } \\
\text { (\% of } \\
108 \text { cases) }\end{array}$ \\
\hline Epigastic fullness & 35 & 38 & 40 \\
Early dumping & 15 & 9 & $21 x$ \\
Late dumping & 8 & 6 & 1 \\
Nausea & 17 & 16 & 8 \\
Food vomiting & 6 & 7 & 2 \\
Bile vomiting & 14 & 11 & 10 \\
Heartburn & 20 & 14 & 11 \\
Flatulence & 13 & 23 & 14 \\
Dysphagia & 0 & 2 & 5 \\
Diarrhoea & 26 & 21 & $12 x$ \\
\hline
\end{tabular}

From Goligher et al. (1966).

TABLE 4

Severity of early dumping

\begin{tabular}{lccc}
\hline Severity & $\begin{array}{c}\text { Vagotomy \& } \\
\text { gastro- } \\
\text { enterostomy } \\
\text { (\% of } 120 \text { cases) }\end{array}$ & $\begin{array}{c}\text { Vagotomy \& } \\
\text { \& antrectomy } \\
\text { \% of }\end{array}$ & $\begin{array}{c}\text { Subtotal } \\
\text { gastrec- } \\
\text { tomy }\end{array}$ \\
Mild & 13 & 7 & of 108 cases) \\
Moderate & 2 & 2 & 15 \\
Severe & 0 & 0 & 5 \\
Total & 15 & 9 & 1 \\
\hline
\end{tabular}

From Goligher et al. (1966).

At the latest follow-up (3-6 years) proven or suspected recurrent ulcers had occurred in $4 \%$ of vagotomy and gastro-enterostomy, $2 \%$ of Polya resections, and $0 \%$ of vagotomy and antrectomy (Table 6).

The preliminary assessment of the 2-year results for sixty-eight vagotomy and pyloroplasties (men) performed in York, and available for analysis since 1963 are not very encouraging, there being eleven, or some $16 \%$, classified as bad results. Of these eleven, four are due to proven recurrent ulceration, there are three with epigastric pain and questionable recurrent ulceration, two with severe diarrhoea, and two with inadequate drainage, requiring further operations.
TABLE 5

Severity of diarrhoea

\begin{tabular}{|c|c|c|c|}
\hline Severity & $\begin{array}{c}\text { Vagotomy } \\
\text { \& gastro- } \\
\text { enterostomy } \\
\text { ( } \% \text { of } \\
117 \text { cases) }\end{array}$ & $\begin{array}{c}\text { Vagotomy } \\
\& \text { antrec- } \\
\text { tomy } \\
\text { (\% of } \\
119 \text { cases) }\end{array}$ & $\begin{array}{c}\text { Subtotal } \\
\text { gastrec- } \\
\text { tomy } \\
\text { ( } \% \text { of } \\
104 \text { cases) }\end{array}$ \\
\hline
\end{tabular}

\begin{tabular}{|c|c|c|c|}
\hline $\begin{array}{l}\text { Mild or moderate } \\
\text { episodic }\end{array}$ & 21 & 18 & 0 \\
\hline Continuous & 1 & 2 & 2 \\
\hline Total & 22 & 20 & 12 \\
\hline $\begin{array}{l}\text { Severe episodic } \\
\text { Continuous }\end{array}$ & $\begin{array}{l}3 \\
1\end{array}$ & $\begin{array}{l}1 \\
0\end{array}$ & $\begin{array}{l}0 \\
0\end{array}$ \\
\hline Total & 4 & 1 & 0 \\
\hline $\begin{array}{l}\text { All forms of } \\
\text { diarrhoea }\end{array}$ & 26 & 21 & 12 \\
\hline
\end{tabular}

From Goligher et al. (1966).

TABLE 6

Recurrent ulceration at latest follow-up

\begin{tabular}{|c|c|c|c|c|c|c|}
\hline $\begin{array}{l}\text { Degree of } \\
\text { certainty }\end{array}$ & & $\begin{array}{l}\text { Vagotomy }+ \\
\text { gastro- } \\
\text { enterostomy } \\
(120 \text { cases })\end{array}$ & & $\begin{array}{l}\text { agotomy } \\
\text { antrectom } \\
\text { (123 cases }\end{array}$ & & $\begin{array}{l}\text { Subtotal } \\
\text { gastrectomy } \\
\text { (108 cases) }\end{array}$ \\
\hline Proven & 2 & $\begin{array}{l}\text { Laparotomy } \\
\text { Laparotomy }\end{array}$ & $\begin{array}{l}+ \\
+\end{array}$ & 0 & & Laparotomyō \\
\hline Suspected & 3 & $\begin{array}{l}1 \text { Laparotomy } \\
2 \text { Melaena]+ } \\
\text { X-ray - }\end{array}$ & + & $\begin{array}{l}0 \\
0\end{array}$ & & melaena + \\
\hline $\begin{array}{l}\text { Very } \\
\text { dubious }\end{array}$ & 3 & $\begin{array}{l}\text { Pain }++ \\
\text { X-ray - }\end{array}$ & & $\begin{array}{l}\text { Pain }++ \\
\text { X-ray - }\end{array}$ & & $\begin{array}{l}\text { Pain }++ \\
\text { X-ray - }\end{array}$ \\
\hline Total & 5 & $(-8)$ & 0 & $(-1)$ & 2( & $(-3)$ \\
\hline
\end{tabular}

From Goligher et al. (1966).

\section{Late results}

Following Polya resections there is a tendency:for a deterioration, at least as judged by clinical 3 . assessment, in the patient's condition with the passage of years. We have followed up 448 of 3 the late Arthur Visick's male patients who hado a Polya resection in the 1940s, and have seen them at yearly intervals; the percentage of goodo results falls with the passage of time, while that of bad results increases (Table 7).

To my mind this is due to two factors ; firstlyn assessments in the first few post-operative years N are apt to be over-optimistic, the patients being ${ }_{\sigma}$ extremely grateful for the relief of pain, and at the same time having undergone a traumatic experience, are often unwilling to admit to minor@ symptoms. Secondly it takes some years before the nutritional effects are fully apparent. 
TABLE 7

Comparative assessment (in percentage) of 448 men having Polya resections, in relation to time after operation, and followed up at yearly intervals for 1-20 years

\begin{tabular}{lrrrr}
\hline \multirow{2}{*}{ Classification } & \multicolumn{4}{c}{ Post-operative time (years) } \\
\cline { 2 - 5 } & \multicolumn{1}{c}{1} & \multicolumn{1}{c}{5} & \multicolumn{1}{c}{10} & $11+$ \\
\hline Good (grades I and II) & $82 \cdot 7$ & $81 \cdot 8$ & $77 \cdot 3$ & $74 \cdot 8$ \\
Moderate (grade II) & 13.6 & 13.9 & $17 \cdot 3$ & 19.0 \\
Bad (grades III and IV) & 3.7 & 4.3 & 5.4 & 6.2 \\
\hline
\end{tabular}

From Pulvertaft (1964).

Today I intend to discuss, briefly, only two aspects of the problem, the effects on nutrition as judged: (1) by body weight, and (2) the blood. The intriguing problem of calcium and bone metabolism is the subject of discussion later.

\section{Influence of surgery on weight}

The immediate effects of different operations on weight are summarized in Fig. 1, which is based on 153 men with duodenal ulcer, whom I have followed from diagnosis to operation, and who have subsequently attended the Gastric Clinic. Of these forty-eight had a Polya resection, fifty-five vagotomy and gastro-enterostomy, twenty-three vagotomy and antrectomy, and twenty-seven vagotomy and pyloroplasty. The pre-operative weight is that recorded within 1-2 years before operation, or the mean of multiple observations. The post-operative weights are expressed as the mean percentage change from the pre-operative weight. Vagotomy with either gastro-enterostomy or pyloroplasty has no appreciable influence on weight. Polya resection results in a large immediate loss $(8 \cdot 3 \%)$ which is reduced to $5.9 \%$ by 1 year, and after that it

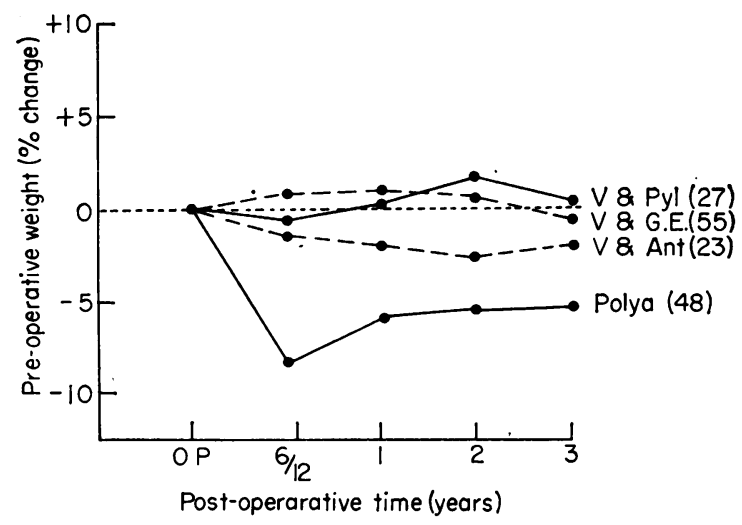

Fig. 1. Effects of different operations on weight (duodenal ulcer in men). remains stable. Vagotomy and small resections of the antrum have a much less pronounced immediate effect-a loss of $1 \cdot 1 \%$ by 6 months, increasing to $2 \cdot 1 \%$ by 1 year.

This weight change is, however, partly influenced by age (Fig. 2). The average change for the 6 months to 3 years post-operative period from the pre-operative weights is shown for two age-groups, below 60 and over 60 ; for each operation there is a greater change in the over-60s than in the younger men, the difference for Polya resections being $9.8 \%$ compared to $5.9 \%$; for antrectomy, $3.3 \%$ to $2.2 \%$; after gastro-enterostomy or pyloroplasty there is a slight loss for the over-60s, compared to a slight gain below 60 .

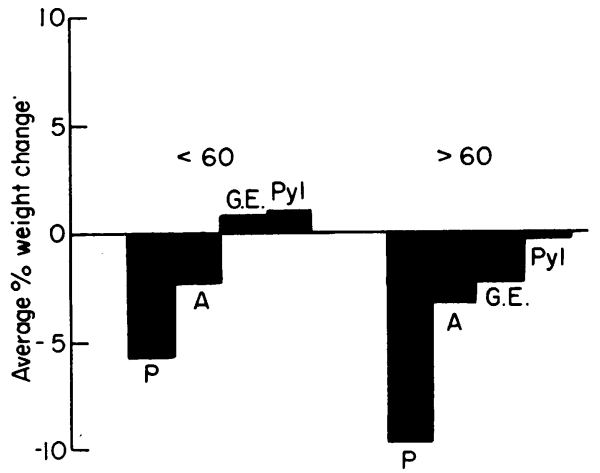

FIG. 2. Average post-operative (6 months to 3 years) change from pre-operative weight for male duodenal ulcer subjects with Polya resection (P), vagotomy with antrectomy (A), vagotomy with gastrenterostomy (G.E.) and vagotomy with pyloroplasty (Pyl.) from preoperative weight for two age groups, below and above 60

This immediate post-operative effect is the basis of later metabolic disturbances, which, usually, take some years to manifest themselves.

It is reasonable to assume that mineral and vitamin deficiencies will be most marked in patients who lose weight, and may be the outcome of either reduced intake or absorption. It does not, necessarily, follow that patients with gastro-enterostomy or pyloroplasty will be free of all such complications. Cox et al. (1964) have shown that nearly $40 \%$ of patients with total vagotomy and gastro-enterostomy have a degree of steatorrhoea, though no relationship was demonstrated between faecal fat estimations and weight-change.

The effect of surgery on the blood

All observers are agreed that gastric resection, in particular Polya-type resections, lead to high 
incidences of anaemia, the exact incidence depending on the definition of anaemia, and, a most important factor, the time from operation, but it is somewhere between 40 and $50 \%$ (Weir \& Gatenby, 1963 ; Mollin \& Hines, 1964). There is, however, far less information about the effects of vagotomy and drainage.

Cox \& Hutchison (1967 personal communication) have shown that 8 years after operation the mean haemoglobin and serum $B_{12}$ are significantly lower following Polya resection than after vagotomy and gastro-enterostomy; the mean serum iron is also lower but the difference is not significant. They, further, compared these subjects with sixty-three unoperated male duodenal ulcers and have shown that the mean haemoglobin and serum iron were significantly lower in men with vagotomy and gastro-enterostomy than in the unoperated group.

In York we have, unfortunately, no data on the early effects of Polya resection on the blood, but we can compare the influence of vagotomy in association with gastro-enterostomy, antrectomy, or pyloroplasty (Table 8). (Patients having haemorrhage within 6 months before operation have been excluded from these figures). By 1 year after surgery the mean haemoglobin for all three operations is lower than the preoperative value; the most marked change follows antrectomy, a fall of some $11.5 \%$. The difference in each case is statistically significant.

\section{TABLE 8}

Comparison of mean haemoglobin before and 1 year after operation for male duodenal subjects aged less than 60 at time of operation

\begin{tabular}{|c|c|c|c|c|c|}
\hline \multirow{2}{*}{ Operation } & \multirow{2}{*}{ No. } & \multicolumn{3}{|c|}{$\begin{array}{c}\text { Mean haemoglobin } \\
(\mathrm{g} / 100 \mathrm{ml})\end{array}$} & \multirow[b]{2}{*}{$P$} \\
\hline & & $\begin{array}{l}\text { Pre- } \\
\text { op }\end{array}$ & $\begin{array}{c}1 \text { year } \\
\text { post-op }\end{array}$ & change & \\
\hline $\begin{array}{l}\text { Vagotomy and } \\
\text { pyloropasty }\end{array}$ & 56 & $15 \cdot 3$ & $14 \cdot 2$ & $-6 \cdot 7$ & $<0.001$ \\
\hline $\begin{array}{l}\text { Vagotomy and } \\
\text { gastro-enterostomy }\end{array}$ & 48 & $15 \cdot 2$ & $14 \cdot 4$ & $-5 \cdot 3$ & $<0.05$ \\
\hline $\begin{array}{l}\text { Vagotomy } \\
\text { and antrectomy }\end{array}$ & 32 & $15 \cdot 6$ & $13 \cdot 8$ & $-11 \cdot 5$ & $<0.001$ \\
\hline
\end{tabular}

The later effects are more difficult to assess as some patients have been treated for anaemia, but the amount of iron prescribed has varied considerably and, moreover, it is impossible to know how much of that prescribed has, in fact, been ingested.

In spite of possible treatment, however, there is a further fall in the mean haemoglobin between 1 and 5 years after operation (Table 9); $5.4 \%$ for vagotomy and gastro-enterostomy and $4.3 \%$ for antrectomy; these differences are not, however, statistically significant. The figures shown here refer to patients aged less than 60 , but similar observations hold for the full agerange.

TABLE 9

Comparison of mean haemoglobin for male duodenal ulcer subjects aged $<60$ at operation, at 1 and 5 years after operation

\begin{tabular}{|c|c|c|c|c|c|}
\hline \multirow{2}{*}{ Operation } & \multirow{2}{*}{ No. } & \multicolumn{2}{|c|}{$\begin{array}{c}\text { Mean haemoglobin } \\
(\mathrm{g} / 100 \mathrm{ml})\end{array}$} & \multirow{2}{*}{$\begin{array}{c}\% \\
\text { change }\end{array}$} & \multirow{2}{*}{$P$} \\
\hline & & 1 year & 5 years & & \\
\hline $\begin{array}{l}\text { Vagotomy and } \\
\text { gastro-enterostomy }\end{array}$ & $47^{*}$ & $14 \cdot 6$ & $13 \cdot 8$ & $-5 \cdot 4$ & N.S. \\
\hline $\begin{array}{l}\text { Vagotomy and } \\
\text { antrectomy }\end{array}$ & 32 & 14.0 & $13 \cdot 4$ & $-4 \cdot 3$ & N.S. \\
\hline
\end{tabular}

* One other known to be anaemic but not recorded at $\vec{\omega}$ 5 years.

At this stage it is impossible to make any $\vec{\gtrless}$ direct comparisons, because of the time differ-

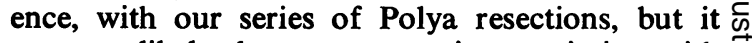
seems unlikely that vagotomy, in association with $\vec{P}$ gastro-enterostomy or pyloroplasty, will result the same high incidences of anaemia. Opinion of antrectomy must be reserved, but it will be of greaf interest to compare, in due course, the late results of antrectomy with the more extensive Polya resections.

This fall in haemoglobin may be, in part, the result of gastro-intestinal haemorrhage, even if $\vec{\overrightarrow{ }}$ not clinically recognized, but this is unlikely to be the full explanation. Current thought tends towards a belief that gastric surgery, in some way, interferes with the absorption of iron, rather than a dietary lack of iron. Our dietary studies over 6-7 days support this view, the mean daily intake of iron being very similar in all three vagotomy operations and comparable with that for seventy-six unoperated male ulcer subjects (Table 10). Eight of the operation group (two

TABle 10

Mean dietary intake of iron (7-day dietary method) for men

\begin{tabular}{lrc}
\hline \multicolumn{1}{c}{ Operation } & No. & $\begin{array}{c}\text { Mean dietary iron } \\
(\mathrm{mg} / \text { day })\end{array}$ \\
\hline Vagotomy and gastro-enterostomy & 16 & $17 \cdot 1$ \\
Vagotomy and antrectomy & 16 & $15 \cdot 8$ \\
Vagotomy and pyloroplasty & 13 & $16 \cdot 5$ \\
Unoperated ulcer subjects & 76 & $16 \cdot 1$ \\
Polya resection & 101 & $15 \cdot 6$ \\
\hline
\end{tabular}


with gastro-enterostomy and six with antrectomy) have had post-operative haemoglobin values of less than $12.5 \mathrm{~g}$, with one exception all eight were taking at least $15.5 \mathrm{mg} /$ day.

It is interesting that the intake for Polya resections is also comparable at $15.6 \mathrm{mg} /$ day.

\section{References}

Cox, A.G., Bond, M.R., Podmore, D.A. \& Rose, D.P. (1964) Aspects of nutrition after vagotomy and gastro-enterostomy. Brit. med. J. i, 465.
Goligher, J.C., Pulvertaft, C.N. \& Franz, R.C. (1966) A comparison of surgical methods in the treatment of duodenal ulcer. Postgraduate Gastro-enterology (Ed. by T. J. Thomson \& I. E. Gillespie). Bailliere, Tindall \& Cassell, London.

HoLT, R.L. \& LYTHGOE, J.P. (1965) The treatment of chronic duodenal ulcer by vagotomy and anterior pylorectomy. Brit. J. Surg. 52, 27.

Mollin, D.L. \& Hines, J.C. (1964) Late post-gastrectomy syndromes. Observations on the nature and pathogenesis of anaemia following partial gastrectomy. Proc. $R$. Soc. Med. 57, 575.

Pulvertaft, C.N. (1964) The late results of gastric resection. Brit. J. Surg. 51, 414.

WeIR, D.G. \& GatenBY, P.B.B. (1963) Sub-acute degeneration of the cord after partial gastrectomy. Brit. med. J. ii. 11175. 